\title{
12. Opening the black box of river basin organisations
}

\author{
Susanne Schmeier \\ Mekong River Commission (MRC)-Deutsche Gesellschaft für \\ Internationale Zusammenarbeit (GIZ) Cooperation Programme, \\ Vientiane, Laos
}

During the past decades, research on the governance of internationally shared river and lake basins provides ample evidence that cooperation can prevail over conflict (Wolf 2007; DeStefano et al. 2010). Scholars have also been able to provide comprehensive explanations for why and under which conditions agreements on shared watercourses are signed and river basin organisations (RBOs) emerge (Song and Whittington 2004; Dinar 2007).

The mere existence of RBOs does not, however, necessarily ensure that waterrelated problems in a shared basin will be solved, nor that the resources of the basin will be managed in a sustainable way. Instead, reality shows that some RBOs have been able to effectively govern their basin while others have failed, or have made limited contributions to the solution of water-related challenges.

In some river basins governed by RBOs, key problems of collective action have been addressed successfully. In the Danube and the Rhine river basins, for instance, the activities of the respective RBOs have significantly contributed to improving the water quality of the rivers. In other basins, however, challenges remain in spite of the existence of the RBO - such as in the Mekong River Basin, where the Mekong River Commission (MRC) is struggling to address conflicts over the use of the river and, in particular, the consequences of unilateral water use projects. And yet in other basins, the activities of an RBO might have addressed some water resources governance challenges, but also caused additional ones. A promiment example is the Senegal River Basin, where joint water resources development projects have been established in order to boost the economic development of the members of the Organisation pour la Mise en Valeur du Fleuve Sénégal (OMVS), but have led to unexpected environmental and social impacts.

While there are a number of potential explanations for such variation in the effectiveness of river basin governance, most often focusing on the nature of the basin itself as well as more general relations among riparian states (see, among others, Marty 2001; Hensel et al. 2006; Dinar 2009), I suggest that it might be the RBOs themselves that matter. That is, the way RBOs are designed and operate as institutionalised forms of cooperation can also be expected to have 
a major influence on water resources governance outcomes. Hence, it is time to open the black box of RBOs. Only understanding the design of RBOs and its effect on their capacity to respond to challenges of water resources governance will enable us to design institutions that will be able to effectively govern shared watercourses.

In order to understand the design of RBOs, and thus build a basis for the analysis of its influence on river basin governance, I propose to differentiate between two institutional design categories:

- the organisational set-up of RBOs, representing the RBO's infrastructure and consisting of its member states/its inclusiveness, its functional scope, its legal bases and water law commitments, its organisational bodies and the role of its secretariat or executive body as well as its financing sources, and

- the water resources governance mechanisms the RBO provides, including decision-making, information-sharing, monitoring or dispute-resolution mechanisms, as well as means for including non-state actors into its river basin governance activities.

Understanding the impact of RBO design on water resources governance requires, as a next step in analysis, a basic understanding of how existing RBOs encompass the aforementioned design characteristics. Since research on the design of RBOs is limited and rarely goes beyond comparative case studies, I have embarked upon establishing a baseline for the institutional design of all RBOs governing internationally shared watercourses (119 in total; see Schmeier 2013). This mapping exercise provides a comprehensive picture of institutionalised river basin governance.

Looking at the membership structure of RBOs - one of the most obvious institutional design features - reveals that the number of member states varies considerably across RBOs, ranging from bilateral RBOs, such as the International Boundary Commission between Canada and the United States, to RBOs with a large number of members - up to 14 in the case of the International Commission for the Protection of the Danube River, or 11 in the cases of the Niger Basin Authority and the Nile Basin Initiative respectively. Even more importantly, RBOs also vary with regard to their inclusiveness; that is, whether they include all riparian states to a basin or a subset of them only.

Similarly, RBOs vary with regard to their functional scope and the issues they cover. While water quantity and quality are the issues addressed most often by RBOs, other issues such as hydropower management, irrigation, or riverbased tourism are less commonly tackled by RBOs. In addition to issue coverage, the baseline scoping exercise has also indicated that RBOs tend to adjust and often expand their functional scope in order to integrate into their work newly arising exogenous challenges, such as climate change. Several RBOs, including the International Lake Constance Conference, the International Commission 
for the Protection of the Rhine, and the MRC, have recently included climate change in their functional scope and initiated a number of related river basin governance activities.

For the second category of institutional design features, the river basin governance mechanisms of an RBO, the analysis has shown that disputeresolution mechanisms vary considerably. While some RBOs lack pre-defined mechanisms for solving emerging disputes among their members, others rely on mechanisms that are outdated (such as the reference to the Commission of Mediation, Conciliation and Arbitration of the Organization of African Unity which ceased to exist after the replacement of the organization by the African Union), leaving few RBOs with readily available mechanisms for addressing disputes among their members.

As indicated by the aforementioned examples, the baseline analysis has shown that RBOs vary considerably in their design. Accordingly, we can expect that such design features will have an influence on whether and to what extent an RBO can govern a river basin sustainably and effectively.

The baseline analysis on the institutional design of RBOs provides an important starting point for future research that investigates the relationship between their design and their performance governing the river basin with which they have been entrusted - especially in light of exogenous conditions, which are often expected to determine whether and to what extent RBOs can be successful in river basin governance. Most importantly, such further research and the detailed investigation of how institutional design matters and which features are most likely to make a difference can also inform policy makers about how to reform existing RBOs and design newly emerging ones. Opening the black box of RBOs can thus contribute to sustainably governing internationally shared water resources - even under adverse exogenous conditions - by providing concrete advice for policy action and thus the proactive governance of water resources in shared basins through institutionalised cooperation among riparian states.

Dr Susanne Schmeier's research focuses on governance of shared water resources and the role institutions play in building resilience to environmental change in internationally shared rivers and lakes. Schmeier currently works as a Technical Advisor to the Mekong River Commission (MRC) in Vientiane, Lao PDR. She can be contacted at Schmeier@transnationalstudies.eu.This article is based on a research project conducted from 2008 to 2012. Findings are published in Schmeier, 2013, Governing International Watercourses, Routledge. Data on the design of all 119 international RBOs is available at the Transboundary Freshwater Dispute Database, http://www.transboundarywaters.orst.edu/ database/index.html. 
Global Water: Issues and Insights

\section{References}

DeStefano, L., Paris, E., DeSilva, L. and Wolf, A., 2010. 'Tracking cooperation and conflict in international river basins: historic and recent trends', Water Policy 12(6):871-84.

Dinar, S., 2007. International Water Treaties: Transboundary river negotiation and cooperation, Routledge, London.

- 2009. 'Scarcity and cooperation along international rivers', Global Environmental Politics 9(1):109-35.

Hensel, P., McLaughlin Mitchell, S. and Sowers II, T., 2006. 'Conflict management of riparian disputes', Political Geography 25:383-411.

Marty, F., 2001. Managing International Rivers. Problems, politics and institutions, Peter Lang, Bern.

Schmeier, S., 2013. Governing International Watercourses. River Basin Organizations and the Sustainable Governance of Internationally Shared Rivers and Lakes, Routledge, London.

Song, J. and Whittington, D., 2004. 'Why have some countries on international rivers been successful negotiating treaties? A global perspective', Water Resources Research 40(5):1-18.

Wolf, A., 2007. 'Shared waters: conflict and cooperation', Annual Review of Environmental Resources 32:3.1-3.29. 
This text taken from Global Water: Issues and Insights by R. Quentin Grafton, Paul Wyrwoll, Chris White and David Allendes, published May 2014 by ANU Press, The Australian National University, Canberra, Australia. 